\title{
Association of breastfeeding, pacifier use, breathing pattern and malocclusions in preschoolers
}

\author{
Sebastião Batista Bueno¹, Telmo Oliveira Bittar², Fabiana de Lima Vazquez³, \\ Marcelo Castro Meneghim ${ }^{4}$, Antonio Carlos Pereira ${ }^{4}$
}

Objective: To evaluate the association of breastfeeding duration, pacifier use and nasal air flow with occlusal disorders among children. Methods: This cross-sectional observational study included 138 children aged 4 and 5 years selected in all the daycare centers of the city of Campo Limpo Paulista, Brazil. Questionnaires were applied to mothers to identify total duration of exclusive breastfeeding and non-nutritive sucking. The independent variables were: Sucking (pacifier, bottle, finger), breastfeeding duration and nasal air flow. The dependent variables were: Open bite, crossbite, overjet, overbite, diastema and maxillary deficiency. Frequency distribution calculations were performed, a chi-square test, the Fisher exact test and, after that, stepwise logistic regression were used for statistical analysis, and the level of significance was set at $5 \%$. Results: The use of a pacifier was the most deleterious factor and increased chances of having open bite in 33.3 times, marked overjet in 2.77 times and posterior crossbite in 5.26 times. Conclusion: There was a significant association between non-nutritive sucking, particularly the use of a pacifier, and occlusal disorders. These findings are important to plan the treatment of preschoolers.

Keywords: Breastfeeding. Malocclusion. Primary dentition.

Objetivo: avaliar a associação do tempo de amamentação natural, tempo de uso de chupeta e aeração nasal em relação a problemas oclusais em crianças. Métodos: foi realizado um estudo observacional transversal com universo de 138 crianças entre 4 e 5 anos, de creches de Campo Limpo Paulista/SP. Foram aplicados questionários às mães com o intuito de identificar o tempo de amamentação natural total e exclusiva e hábitos deletérios. Utilizaram-se as variáveis independentes hábitos deletérios (chupeta, mamadeira e dedo), tempo de amamentação natural e aeração nasal; e as variáveis dependentes mordida aberta, mordida cruzada, overjet, sobremordida, presença de diastema e atresia. Foram realizados cálculos das distribuições das frequências, teste de associação do qui-quadrado, exato de Fisher e, em seguida, regressão logística pelo método de stepwise, utilizando nível de significância de 5\%. Resultados: o uso de chupeta foi considerado o mais prejudicial dos hábitos deletérios, aumentando em 33,3 vezes a chance de mordida aberta; 2,77 vezes a chance de apresentar overjet acentuado e 5,26 vezes as chances de apresentar mordida cruzada posterior. Conclusão: houve uma forte associação entre hábitos deletérios (especialmente o tempo de uso de chupeta) e problemas oclusais, sendo esse fato importante no planejamento do tratamento de pacientes pré-escolares.

Palavras-chave: Aleitamento materno. Má oclusão. Hábitos. Dentição decídua.

${ }^{1}$ Professor of Orthodontics, State University of Southwest Bahia.

${ }^{2}$ Professor of Orthodontics, Federal University of Campina Grande.

${ }^{3} \mathrm{MSc}$ in Immunobiology Technology, BioManguinhos Unit, Oswaldo Cruz

Foundation - Fiocruz.

${ }^{4}$ Professor of Virology, Federak University of Rio de Janeiro.

Submitted: August 8, 2008 - Revised and accepted: March 11, 2009

\footnotetext{
How to cite this article: Bueno SB, Bittar TO, Vazquez FL, Meneghim MC, Pereira AC. Association of breastfeeding, pacifier use, breathing pattern and malocclusions in preschoolers. Dental Press J Orthod. 2013 Jan-Feb;18(1):30.el-6.

» The authors report no commercial, proprietary or financial interest in the products or companies described in this article.

Contact address: Telmo Oliveira Bittar

Rua 12, 316 - Centro

CEP: 38.300-062 - Ituiutaba/SP - Brazil

E-mail: telmobittar@fop.unicamp.br
} 


\section{INTRODUCTION}

Exclusive breastfeeding is the main source of food for the development of infants, a free and exceptional source of nutritional energy that generates immunological, neurological, emotional and speech benefits due to the physiological act of sucking. ${ }^{1-4}$

In addition to its nutritious advantage, it is also decisive and primordial for the correct stimulation of growth and development of facial structures, as it exercises the oral and facial muscles, which then promotes the development of physiological functions. ${ }^{5}$

This physiological function produces neural stimulation and, consequently, the anteroposterior development of the mandible and the perfect modeling of gonion angles, ${ }^{6}$ a process that begins in newborns and extends until the eruption of the first deciduous teeth. Breastfeeding directly affects the movement pattern of masticatory muscles and promotes correct swallowing and breathing. ${ }^{4}$

A shorter breastfeeding duration increases the frequency of non-nutritive sucking, and the relative risk is seven times higher in comparison with infants exclusively breastfed for at least six months. Infants that use bottles for over one year have a ten times greater possibility of developing non-nutritive sucking than infants that never used a feeding bottle, which leads to the conclusion that non-nutritive sucking is strongly associated with malocclusions. ${ }^{4,7,8,9}$

The lack or absence of breastfeeding is correlated with the underdevelopment of the masticatory complex, atypical swallowing, oral or mixed breathing and, consequently, the appearance of malocclusions.

It is believed that, if non-nutritive sucking persists up to three years of age, children have less serious changes in occlusion, generally affecting only the anterior region of the jaws. After stimulation is removed, these structures continue their normal growth and retain their occlusal balance. However, when sucking persists for a longer time, it usually leads to significant occlusal disorders, such as: Open bite, maxillary deficiency, underdevelopment of the mandible and maxillary projection. ${ }^{13,14}$

The increase in malocclusion cases, according to several epidemiological studies, has been associated with industrialization, urban life, cultural transformations and changes in functional habits, particularly eating, in a short period of time. ${ }^{15,16}$ This finding con- firms the hypothesis that all problems of our stomatognathic system, except a few cases, have their origin in the masticatory functional atrophy due to our civilized eating regime. ${ }^{6}$

The study of such effects is fundamentally important and relevant to define scientific parameter to be used in raising the awareness of healthcare professionals, and orthodontists to prevent and control malocclusion disorders by means of multidisciplinary actions in the area of collective health.

This study analyzed the correlation between malocclusion and unhealthy habits and their possible associations with breastfeeding duration in infancy.

\section{MATERIAL AND METHODS}

This cross-sectional study included all the students $(n=138)$ aged 4 and 5 years enrolled in four municipal day-care centers in the city of Campo Limpo Paulista, Brazil. During a previous contact with the day-care center managers, the characteristics and objectives of the study were explained and informed consent terms signed by parents or guardians were obtained. The sample was composed of boys and girls. The students were examined to check the presence of malocclusion. A questionnaire in the form of a structured interview was applied to find out about breastfeeding duration, bottle feeding, pacifier and finger sucking.

Clinical data were obtained according to the Dental Aesthetics Index (DAI) recommended by the World Health Organization, and malocclusion was diagnosed in students that had open bite, posterior crossbite and overjet.

An Altmann graded mirror ${ }^{17}$ was used to measure the condensation area produced by nasal air flow.

First, a chi-square test or the Fisher exact test was used for univariate analysis to check the level of association between variables $(\alpha=0.05)$. After that, stepwise logistic regression was used to determine the effect of non-nutritive sucking. The dependent variables were: Anterior open bite, overjet, overbite, posterior crossbite and maxillary deficiency. The independent variables were: Breastfeeding duration, exclusive breastfeeding duration, pacifier use duration and nasal air flow condensation area.

All the forms of non-nutritive sucking were included in the logistic regression, and the effect was estimated using odds ratio (OR) and 95\% confidence intervals. 
The SAS software (SAS Institute Inc., Cary, NC, USA, Release 8.2, 2001) was used for all statistical calculations.

\section{RESULTS}

Duration of pacifier use was a risk indicator for marked open bite. The chance of having marked open bite was 33.3 times greater in children that used a pacifier for longer than 3 years.

The chance of having a diastema was 2.43 times greater among children with a nasal air flow condensation area smaller than $12 \mathrm{~cm}^{2}$. Children that breathe through the mouth may have a functional disorder called atypical lingual positioning, which may lead to marked buccal inclination of maxillary and mandibular incisors and result in several diastemas in the anterior region.

The risk indicator for overjet was duration of pacifier use. Children that used a pacifier for more than 3 years had a 2.77 times greater chance of having an overjet $>5 \mathrm{~mm}$.

The risk indicator for overbite was duration of pacifier use, and chances of having overbite were 12.32 times greater among children that used a pacifier for up to 3 years. The chance of having overbite among children that were breastfed for 0 to 6 months was 2.78 greater than for those that were breastfed for 6 months or longer.

The risk indicator for posterior crossbite was duration of pacifier use and nasal air flow condensation area. The chance of having posterior crossbite was 5.26 times greater in children that used a pacifier for longer than 3 years. Chances of having posterior crossbite were 7.81 times greater among children that had a nasal airflow condensation area smaller than $12 \mathrm{~cm}^{2}$.

The risk indicators for maxillary deficiency were duration of pacifier use and nasal air flow condensation area. Children that used a pacifier for more than 3 years had a 4.61 times greater chance of having maxillary deficiency. Chances of having maxillary deficiency were 5.29 times greater among children that had a nasal air flow condensation area smaller than $12 \mathrm{~cm}^{2}$.

\section{DISCUSSION}

In healthcare and dentistry, two fields that are not only complementary, but also inseparable in pediatrics, breastfeeding is more than a type of food chosen according to scientific knowledge and that may be replaced due to so-called "professional" or personal decisions; it is, rather, something of special relevance in the comprehensive psychological, emotional, immunologic and functional development of infants.

This study found that $29.7 \%$ of the children had already been weaned in the third month of life, and $55.8 \%$ in the sixth month; only $25.4 \%$ of the infants were still breastfed at 12 months of life. The World Health Organization recommends that infants should be breastfed for at least twelve months, and that breastfeeding should be extended to the $24^{\text {th }}$ month in poor countries. ${ }^{19}$

The comparison of breastfeeding and pacifier use revealed that the frequency of pacifier use was greater among children that were breastfed for a shorter time. In agreement with authors that analyzed the use of a pacifier for longer than three years, our comparisons of the breastfeeding groups are in agreement with findings reported by Farsi, ${ }^{20}$ who showed that the prevalence of pacifier sucking is low among children that are breastfed for a longer time, and that children breastfed for a shorter time maintain nonnutritive sucking more frequently, ${ }^{21}$ and their risk is seven times greater than that of children breastfed for at least six months.

Sucking, an essential natural reflex in the beginning of life, becomes less frequent as the child becomes more mature physically and emotionally, and tends to stop before 4 years of age. When that does not occur, persistent sucking, called non-nutritive, is associated with deficient breastfeeding. ${ }^{9}$ Children that used a pacifier for longer than 3 years had a 5.26 times greater risk of having posterior crossbite.

Of the children that used a bottle for one year or longer ( $n=121), 90$ had non-nutritive sucking habits, and children that were bottle-fed for one year or longer had an eight times greater chance of using a pacifier or sucking their thumb than children that were never fed with a bottle. These findings are in agreement with those reported in the study conducted by Serra-Negra, ${ }^{9}$ who found a ten times greater risk of non-nutritive sucking among children that used a bottle than among those that never used it.

The use of a pacifier, as well as all other forms of non-nutritive sucking, has been the focus of discussions, but its persistent use, that is, for over three years, usually produces significant occlusal disorders. 
Table 1 - Logistic regression of independent variables in relation to outcome variables: Open bite, diastema, overjet, deep overbite, posterior crossbite and maxillary deficiency.

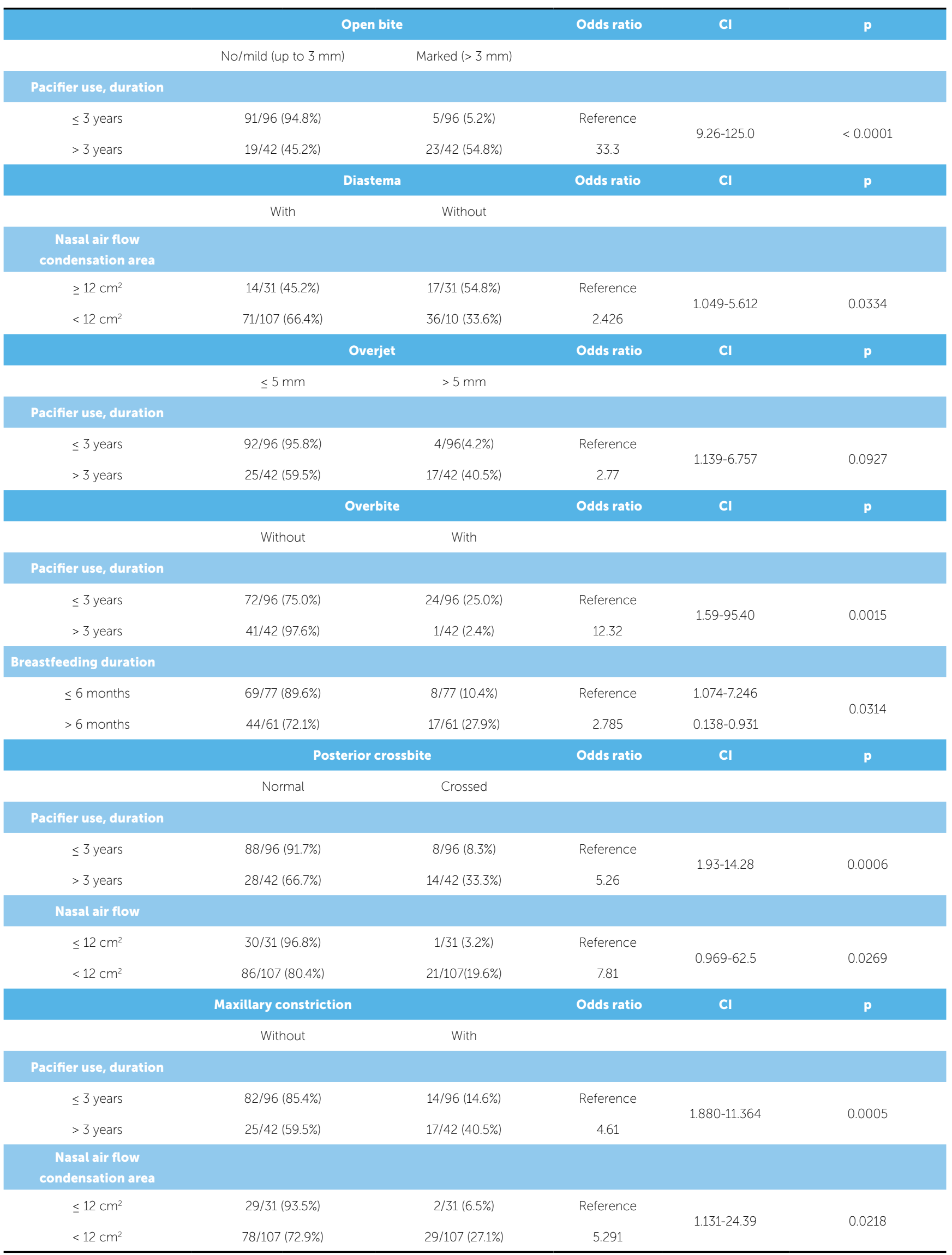


The association of anterior open bite with use of pacifier or finger sucking and simultaneous breastfeeding indicated the risk of severe anterior open bite among those that used a pacifier persistently. The use of more marked results, over $3 \mathrm{~mm}$, is based on the fact that a small vertical overlap is considered normal in the deciduous dentition. ${ }^{23,24}$

Logistic regression showed that the chance of developing an open bite among children that use a pacifier was 33.3 times greater. This result is in agreement with those reported by Ricketts ${ }^{25}$, Moyers ${ }^{22}$ and Lino, ${ }^{13}$ who unanimously found that persistent use of a pacifier, that is, for over three years, leads to the development of occlusal disorders.

According to Ricketts, ${ }^{26} 0.5$ to $4.5 \mathrm{~mm}$ are normal overjet measures in cephalometry. Based on those authors, overjet was divided into two groups, 0.5 to $5 \mathrm{~mm}$ and greater than $5 \mathrm{~mm}$, and then analyzed in relation to breastfeeding duration and sucking. The main result was duration of pacifier use, and logistic regression showed that a risk indicator of overjet over $5 \mathrm{~mm}$ was use of pacifier for more than 3 years, which revealed that children with persistent non-nutritive sucking had a 2.77 greater chance of having marked overjet. These results showed that the prolonged use of a pacifier is a risk indicator of marked overjet. ${ }^{27}$

There was an association of posterior crossbite and maxillary deficiency with breastfeeding and non-nutritive sucking. The risk indicator is prolonged use of a pacifier, at 5.26 and 4.61 greater chances of posterior crossbite and maxillary deficiency among chil- dren that continue using a pacifier for more than 3 years. These findings are particularly important for orthodontic planning and treatment, and the effect of these factors in this age group is fundamental.

The use of a pacifier is associated with overbite, and the children that used a pacifier for a longer time had lower chances of having overbite. This does not mean that pacifier sucking is a protective factor against overbite. In fact, non-nutritive sucking dynamically increased the chances of open bite and reduced the percentage of children with overbite in the group that used a pacifier for a long time.

Children that were breastfed for a short time (0 to 6 months) has a 2.78 times greater chance of having overbite than children that were breastfed for 7 months or longer. This result confirms findings by Kohler, who recommended breastfeeding because breast sucking movements stimulate the motor and sensorial systems and promote balanced mandibular movements, which support the development of the stomatognathic system.

\section{CONCLUSION}

1) Breastfeeding affects the prevalence of non-nutritive sucking, especially persistent sucking.

2) Persistent non-nutritive sucking affects the prevalence of malocclusion and compromises nasal breathing.

3) Breastfeeding promotions contribute to the prevention of non-nutritive sucking, mouth breathing and malocclusion. 


\section{REFERENCES}

1. Almeida MF. Nutrição e cuidados com o recém-nascido. Pediatr Mod. 1992:28(1):5-7

2. Carvalhaes MABL, Parada CMGL, Manoel CM, Venâncio SY. Diagnóstico da situação do aleitamento materno em área urbana do Sudeste do Brasil: utilização de metodologia simplificada. Rev Saúde Pública. 1998:32(5):430-6

3. Gigante DP, Victora CG, Barros FC. Nutrição materna e duração da amamentação em uma Coorte de nascimentos de Pelotas-RS. Rev Saúde Pública. 2000:34(3):259-65.

4. Gimenez CMM, Moraes ABA, Bertoz AP, Bertoz FA, Ambrosano GB. Prevalência de más oclusões na primeira infância e sua relação com as formas de aleitamento e hábitos infantis. Rev Dental Press Ortod Ortop Facial. 2008:13(2):70-83

5. Carvalho GDSOS. Respirador bucal, uma visão funcional e clínica da amamentação. São Paulo: Lovise; 2003.

6. Planas P. Reabilitação neuroclusal. 2ª ed. Rio de Janeiro: Medsi; 1997 $355 \mathrm{p}$.

7. Peres KG, Barros AJD, Peres MA, Victora CG. Efeitos da amamentação e dos hábitos de sucção sobre as oclusopatias num estudo de coorte. Rev Saúde Pública. 2007:41(3):343-50.

8. Robles FRP, Mendes FM, Haddad AE, Corrêa MSNP. A influência do periodo de amamentação nos hábitos de sucção persistentes e a ocorrência de maloclusões em crianças com dentição decídua completa. Rev Paul Odontol. 1999;21(3):4-9.

9. Serra-Negra JMC. Estudo da associação entre aleitamento, hábitos bucais e maloclusões. Rev Odontol Univ São Paulo. 1997:11(2):79-86.

10. Souza DFRK, Valle MAS, Pacheco MCT. Relação clínica entre hábitos de sucção, má oclusão, aleitamento e grau de informação prévia das mães. Rev Dental Press Ortod Ortop Facial. 2006;11(6):81-90.

11. Carvalho GD. Amamentação é prevenção das alterações funcionais e estruturais do sistema estomatognático. Odontol Ens Pesq 1998:2(1):339-48

12. Costa COM, Figueiredo EM, Silva SB. Aleitamento materno: causas de desmame e justificativas para amamentar. J Pediatr. 1993;69(3):177-8.

13. Lino AP. Introdução ao problema da deglutição atípica. In: Interlandi S. Ortodontia: bases para iniciação. 4a ed. São Paulo: Artes Médicas; 1999 Cap. 23.

14. Moyers R. Etiologia da má oclusão. In: Moyers RE. Ortodontia. 4a ed. Rio de Janeiro: Guanabara Koogan; 1991. p. 212-37.
15. Varrela J. Occurrence of malocclusion in attritive environment: a study of a skull sample from southwest Finland. Scand J Dent Res 1990:98(3):242-7

16. Cavalcanti AL, Bezerra PKM, Moura C. Aleitamento natural, aleitamento artificial, hábitos de sucção e maloclusões em pré-escolares brasileiros. Rev Saúde Pública. 2007;9(2):194-204.

17. Altmann EBC, Gadella MEC. Insuficiência e incompetência velofaríngea. In: Sih T. Otorrinolaringologia pediátrica. Rio de Janeiro: Revinter; 1998. p. 387-93.

18. Carvalho GD. Amamentação e o sistema estomatognático. In Carvalho MR, Tamez RN. Amamentação bases científicas para a prática profissional. Rio de Janeiro: Guanabara Koogan; 2002. p. 36-49.

19. World Health Organization. Expert consultation on optimal duration of exclusive breastfeeding. Geneva 28-30 March 2001

20. Farsi NMA. Sucking habits in Saudi children: prevalence contributing factors and effects on the primary dentition. Pediatr Dent. 1996:63(6):403-7.

21. Luz CFL, Garib DG, Arouca R. Association between breastfeeding duration and mandibular retrusion: a cross-sectional study of children in the mixed dentition. Am J Orthod Dentofacial Orthop. 2006:130:531-4

22. Moyers R. Ortodontia. 3a ed. Rio de Janeiro: Guanabara Koogan;1988. p. 212-37; 267-72

23. Guedes-Pinto AC. Odontopediatria. 6a ed. São Paulo: Ed. Santos; 1997.

24. Ricketts RM. The value of cephalometrics and computerized technology. Angle Orthod. 1969:55:795-803.

25. Ricketts RM. Clinical research in orthodontics. In: Ricketts RM. Vistas in orthodontics. 5th ed. Fhiladelphia: Lea \& Febiger; 1962.

26. Ricketts RM. Esthetics, environment and the law of lip relation. Am J Orthod. 1969:55:795-803.

27. Van der Linden FPGM. Crescimento e Ortopedia Facial. 2a ed. São Paulo: Ed. Santos: 1990. 244 p.

28. Viazis AD. Atlas de Ortodontia: princípios e aplicações clínicas. 1a ed. São Paulo: Ed. Santos; 1996. p. 345

29. Köhler NRW. Distúrbios miofuncionais: considerações sobre seus fatores etiológicos e conseqüências sobre o processo de crescimento/ desenvolvimento da face. Rev Dental Press Ortod Ortop Facial. 2000:5(3):66-79 